\title{
TUNAS
}

JURNAL PENDIDIKAN GURU PENDIDIKAN DASAR

http://journal.umpalangkaraya.ac.id/index.php/tunas

Volume 6 Nomor 1, Desember 2020 (36-45)

\section{PENGARUH LAYANAN TAMAN BACAAN MASYARAKAT (TBM) RANSEL BUKU DIMASA PENDEMI COVID-19 DALAMI MENINGKATKAN MINAT PENGUNJUNG \\ (Studi Pada TBM Ransel Buku di Petuk Katimpun Kota Palangka Raya) \\ The Effect Of The Community Reading Park (Crp) Ofransel Buku Services In \\ The Pandemic Era In Improving The Visitors' Interest \\ (A Study At The Crp Of Ransel Buku In Petuk Katimpun, Palangka Raya) \\ 'Saiffullah Darlan, ${ }^{2}$ Seth Miko dan ${ }^{3}$ Wahidin \\ Universitas Palangka Raya, Palangka Raya, Kalimantan Tengah, Indonesia \\ 2Universitas Palangka Raya, Palangka Raya, Kalimantan Tengah, Indonesia \\ 3 Universitas Palangka Raya, Palangka Raya, Kalimantan Tengah, Indonesia}

\section{ARTIKEL INFO}

Diterima

September 2020

Dipublikasi

Desember 2020

*e-mail :

1fuldarlan@gmail.com

2sethmiko@yahoo.co.id

3wahidin.dikdas@gmail.c

om
ABSTRAK

Tujuan dilaksanakan penelitian ini adalah untuk mendeskripsikan bagaimanapengaruh layanan Taman Bacaan Masyarakat (TBM) Ransel Buku dimasa pendemi Covid-19 dalam meningkatkan minat pengunjung. Penelitian dilaksanakan menggunakan metode kuantitatif dengan populasi seluruh komponen yang terlibat aktif pada aktivitas keseharian TBM Ransel Buku, terutama dengan aktivitas keterampilan dan keberaksaraan masyarakat. Teknik pengambilan sampel penelitian ini adalah sampling bertujuan (purposive sampling) terdiri 20 orang pengunjung. Instrumen pengumpulan data disesuaikan dengan variabel penelitian, untuk mengukur layanan pada TBM Ransel Buku, berupa observasi langsung, serta untuk mengukur variabel terhadap minat pengunjung menggunakan angket dan studi dokumentasi. Analisis penelitian dilakukan pada $\alpha=0,05$ syarat bahwa butir soal dikatakan valid adalah $r_{\text {hitung }}>r_{\text {tabel. }}$ Namun,jika $r_{\text {hitung }}<r_{\text {tabel }}$ maka dinyatakan tidak valid. Hasil analisis data didapatkan bahwa: I). Layanan TBM Ransel Bukudi masa pendemi covid-19 dalam meningkatkan minat pengunjung ternyata menurun jika dibandingkankan sebelum masa pendemi Covid-19. 2) Life skill sangat diutamakan TBM Ransel Buku, karena pengunjung termotivasi dan berdampak positif untuk belajar. 3). Alternatif pendekatan layanan TBM Ransel Buku untuk menstimulasi minat warga belajar berupa bedah buku, lomba membaca puisi, lomba menulis cerpen cerita rakyat, lomba stand up comedy, serta lomba mewarnai untuk anak usia dini.

Kata kunci: Kualitas Layanan, Taman Bacaan, Pandemi Covid-I9.

\section{ABSTRACT}

This research aimed to describe how the Community Reading Park of RanselBukuin the Pandemic Era improves visitors' interest. This research was conducted using quantitative methodswith a population of all components actively involved in the daily activities of Community Reading Park (CRP) of RanselBuku, especially with skills and community literacy activities.The sampling technique for this research was purposive sampling consisting of 20 visitors. The data collection instrument was adjusted to the research variables to measure the service at the Community Reading Park (CRP) of Ransel Buku, which included direct observation and to measure the variables towards visitors' interest by using questionnaires and documentation. The research analysis was conducted at $\alpha=0,05$ condition that the item was said to be valid was $r_{\text {count }}>r_{\text {table. }}$. However, if $r_{\text {count }}<r_{\text {tablethen }}$ it is declared invalid. The result of the data analysis was I). Community Reading Park (CRP) of RanselBuku services during the pandemic period in improving their visitors' interest decreasedcompared with the previous period. 2). Life skills are prioritized byCommunity Reading Park (CRP) of RanselBuku, because visitors are motivated and positively impact learning.3). Alternative approaches to Community Reading Park (CRP) of RanselBukustimulate citizens' interest in learning in the form of book reviews, various competitions; reading poetry, writing short stories from folk tales, stand-up comedy, and coloring competitions for early childhood.

Keywords: Quality of services, reading park, pandemic. 
Jurnal Pendidikan Guru Sekolah Dasar PENDAHULUAN

Salah satu faktor yang menentukan majunya suatu negara terletak pada seberapa besar negara tersebut memiliki sumber daya manusia (SDM) berkualitas yang dihasilkan dari dunia pendidikan. Di Indonesia untuk menciptakan SDM yang berkualitas tersebut dilaksaakan melalui jalur pendidikan informal, formal dan nonformal, sementara akses untuk mendapatkan pendidikan di jalur pendidikan formal sangat terbatas. Bagi anak usia sekolah yang dikarenakan sesuatu hal orang tuanya tidak mampu menyekolahkan anaknya baik itu ke SD/MI, SMP/MTs dan SMA/MA, atau mau masuk sekolah formal menjadi peserta didik baru namun terganjal masalah batas usia anak sudah melebihi ketentuan yang dipersyaratkan, kepada mereka yang tidak bisa bersekolah ke sekolah formal ini pada akhirnya menjadi miskin yang dikarenakan tidak memiliki pendidikan dan keterampilan (life skill). Program pendidikan life skill adalah pendidikan yang dapat memberikan bekal keterampilan yang praktis, terpakai, terkait dengan kebutuhan pasar kerja, peluang usaha dan potensi ekonomi atau industri yang ada di masyarakat life skill mengacu pada berbagai ragam kemampuan yang diperlukan seseorang untuk menempuh kehidupan dengan sukses, bahagia dan secara bermartabat di masyarakat (Wayan Tamba, Rizka, dan lka Andriani, 2020).

Sebagai alternatif untuk mengatasi terbatasnya kesempatan bisa mendapatkan akses pendidikan untuk belajar di sekolah formal agar anak serta masyarakat bisa belajar, maka tidak ada cara lain adalah melalui jalur pendidikan nonformal atau pendidikan Luar Sekolah (PLS) atau Pendidikan Masyarakat (Dikmas), sebagaimana diamanatkan dalam UU No. 20 Tahun 2003 tentang Sistem Pendidikan Nasional pada Pasal I 3 (I) dijelaskan bahwa jalur pendidikan terdiri atas pendidikan formal, nonformal dan informal yang dapat saling melengkapi dan memperkaya.
Hadirnya Taman Bacaan Masyarakat (TBM) Ransel Buku yang berlokasi di Petuk Katimpun Kota Palangka Raya ini merupakan jawaban atas keterbatasan sekolah formal untuk melayani warga belajar yang tidak bisa mendapatkan pendidikan di sekolah formal, selain itu TBM Ransel Buku ini juga ikut mendukung program pendidikan sepanjang hayat (life long education), sehingga warga belajar terbantu dalam mengaktualisasikan dirinya (self actualizing) dalam memperluas wawasan diri (the expansion of self).

Keberadaan TBM Ransel Buku sebagai lembaga dalam mengembangkan budaya baca dan minat baca masyarakat, menyediakan berbagai program kegiatan seperti kejar paket dan kursus-sursus yang memberikan keterampilan kepada warga belajar, namun yang lebih dominan adalah tujuannya untuk meningkatkan minat baca masyarakat. Keberadaan taman bacaan masyarakat (TBM) merupakan bagian dari kebutuhan masyarakat yang semakin berkembang. Terbentuknya TBM dimaksudkan untuk mendukung gerakan pemberantasan buta aksara, membantu mempercepat tumbuhnya aksarawan baru sekaligus memelihara dan meningkatkan kemampuan baca tulis masyarakat. (Octroaica Cempaka Jene, Yuniwati BYPMYRR dan Yuli Rohmiyati, 2013).

Namun sejak marebaknya wabah pandemi Covid-19 saat ini maka sedikit banyak berpengaruh terhadap layanan TBM Ransel Buku dalam meningkatkan minat pengunjung, atas tersebutmaka tim peneliti tertarik untuk melakukan studi melalui suatu penelitian, dengan rumusam masalah: I) bagaimana pengaruh layanan Taman Bacaan Masyarakat (TBM) Ransel Buku dimasa pendemi covid-19 dalam meningkatkan minat pengunjung; dan 2) Apakah sistem pelayanan tersebut berpengaruh terhadap jumlah pengunjung TBM Ransel Buku semasa Covid19. 


\section{Jurnal Pendidikan Guru Sekolah Dasar \\ METODOLOGI PENELITIAN}

Penelitian dilaksanakan di TBM Ransel Buku yang berlokasi di Petuk Katimpun Kota Palangka Raya menggunakan metode kuantitatif. Metode penelitian kuantitatif pada umumnya melibatkan proses pengumpulan, analisis, dan interpretasi data, serta penulisan hasil-hasil penelitian. (John W. Cresswell, 2017). Kebanyakan teknik-teknik data kuantitatif merupakan kondensor data. Mereka mengikhtiarkan (condense) data agar dapat melihat gambaran secara luas. (W. Lawrence Neuman, 2016).

Populasi penelitian ini seluruh komponen yang terlibat aktif pada aktivitas TBM Ransel Buku dengan sampling bertujuan (purposive sampling) berjumlah 20 orang pengunjung. Instrumen pengumpulan data dilakukan melalui angket, observasi dan dokumentasi. Analisis data dilakukan menggunakan beberapa instrumen: I) skala Likert dalam bentuk daftar check list $(\checkmark)$ dengan 5 pilihan jawaban; 2) uji kelayakan instrumen, terdiri dari: (a) uji validitas dilakukan dengan cara menganalisis butir instrumen dan membandingkan $r_{\text {hitung }}$ dengan $r_{\text {tabel }}$ dengan menggunakan teknik product moment dengan rumus sebagai berikut.

$$
\begin{gathered}
r_{x y}= \\
\frac{n\left(\sum x y\right)-\left(\sum x\right)\left(\sum y\right)}{\left.\left.\sqrt{(n} \sum x^{2}\right)-(x)^{2}\right)\left(n\left(\sum y^{2}\right)-(y)^{2}\right)}
\end{gathered}
$$

Sumber: Arikunto, S. (2006).

(b) perhitungan reliabilitas merupakan perhitungan terhadap ketetapan atau konsistensi dari angket dengan menggunakan rumus Alpha. Penggunaan rumus ini disesuaikan dengan teknik scoring yang dilakukan pada setiap item dalam instrumen. Rumus Alpha adalah:

$$
r_{11}=\left[\frac{k}{(k-1)}\right]\left[1-\frac{\sum \sigma_{b}^{2}}{\sigma^{2}{ }_{t}}\right]
$$

Sumber: Arikunto, S. (2006).
Sebagai indikator keberhasilan penelitian ini dapat dilihat melalui aspek berikut: I) koefisien jumlah pengunjung TBM Ransel Buku setiap minggunya. 2) jumlah koleksi bahan bacaan yang update, baik buku cetak, majalah, koran maupun e-book. 3) tanggapan masyarakat, dalam hal ini pengunjung TBM Ransel Buku, dan 4) jumlah aktivitas layanan bahan bacaan yang dapat membantu pengunjung untuk dapat melakukan kegiatan membaca dalam rangka belajar, mencari informasi, mencari hiburan edukatif atau hanya sekedar mengisi waktu luang.

\section{HASIL DAN PEMBAHASAN}

Ransel Buku pada awalnya hanya merupakan sebuah program membawa buku dan membaca secara sukarela untuk anakanak di desa. Program ini digagas oleh Aini Abdul, seorang pemandu wisata yang bekerja untuk sebuah perusahaan multinasional bergerak di bidang eko-wisata di Palangka Raya, Kalimantan Tengah.Melalui pekerjaannya sebagai seorang pemandu wisata, Aini dapat mengunjungi desa-desa masyarakat yang mayoritasnya penduduknya adalah suku Dayak di bantaran sungai Rungan dan Kahayan. Saat bertugas, la melihat masih banyak sekali desa dengan lokasi cukup dekat ke Kota Palangka Raya (yang merupakan Ibukota Provinsi Kalimantan Tengah), namun masih jauh tertinggal dalam berbagai bidang. Ada banyak faktor yang berkontribusi pada ketertinggalan ekonomi dan pendidikan masyarakat setempat.

Namun demikian, sebagian besar sekolah-sekolah ini tidak memiliki perpustakaan atau jika memiliki perpustakaan kondisinya cukup memprihatinkan. Buku-buku sudah usang atau hanya buku-buku yang melingkupi mata-mata pelajaran yang diajarkan di sekolah saja. Juga saat itu sebagian anakanak sudah kenal akan kenakalan remaja misalnya merokok, ngelem, obat terlarang. 
Jurnal Pendidikan Guru Sekolah Dasar

Kegiatan ini pertama kali dilakukan pada tahun 2009, setelah mendapatkan izin dan dukungan untuk bergerak sebagai sukarelawan dari tokoh adat dan tetua desa, Aini dan kelompoknya menggalakkan kegiatan membaca dua kali seminggu di setiap akhir pekan dari satu desa ke desa lainnya. Kegiatan membaca bersama anak-anak di lakukan di banyak tempat. Pada tahun 2012, Aini bertemu dengan Fery Irawan. Seorang pemuda dari Desa Petuk Katimpun. Berdasarkan pengamatan dan data yang dikumpulkan oleh Aini dan Fery pada sebuah survey sosial ekonomi masyarakat di desa Katimpun pada tahun 2012, masyarakat desa yang menjadi sampel survey menyampaikan beberapa isu penting yang mereka sedang hadapi. Diantaranya adalah sangat rendahnya pendidikan dan terbelakangnya kondisi perekonomian karena banyaknya tantangan kerusakan lingkungan hidup yang berimbas pada mata pencaharian masyarakat. Sungai sumber kehidupan masyarakat Dayak yang mengalami pencemaran tambang emas liar serta sampah.

Pada tahun 2015, sebagai upaya peningkatan kapasitas pengajar di desa, Ransel Buku mengajukan sebuah proposal pada program pelatihan yang diselenggarakan oleh Green School di Bali. Pelatihan ini meliputi pengajaran pendidikan lingkungan hidup sebagai fokus utama, juga menggembleng kepribadian mandiri serta jiwa kepemimpinan pada peserta pelatihan. Fery belajar selama enam bulan melalui program pelatihan ini. Sekembalinya dari pelatihan di Bali sejak Januari 2016, Fery kini mengajarkan lebih banyak program berbasis lingkungan hidup untuk anak-anak melalui praktik langsung daur ulang dan pengelolaan sampah plastik dan lain sebagainya. Fery bersama para peserta pelatihan pendidikan lingkungan hidup di Green School, Bali Selain itu, Ransel Buku juga mulai membangun sebuah sanggar seni Dayak Ngaju di tahun yang sama untuk anak-anak binaan di desa agar bisa mempelajari kearifan dan keindahan budaya Dayak yang sedang menghadapi kemunduran akibat digerus oleh jaman. Karenanya di tambahkan lagi kelas musik dan tari pada kelas-kelas yang sudah ada.

Visi dan Misi TBM Ransel Buku

Dalam visi dan misi TBM Ransel Buku ini terdapat impian yang harus di capai, citacita termasuk inti dari organisasi. Misi adalah suatu proses atau tahapan yang dapat di lalui suatu lembaga atau instansi yang di dirikan baik perorangan maupun pemerintah terdapat visi dan misi guna untuk mencapai tujuan yang di inginkan. Visi adalah rangkaian kata oleh lembaga atau organisasi dengan tujuan bisa mencapai visi tersebut. Berikut adalah visi dan misi TBM Ransel Buku adalah:

\section{Visi dan Misi \\ Visi}

Menjadi agen perubahan positif di tengah masyarakat Kalimantan Tengah melalui literasi

Misi
a. Menjalankan program pustaka bergerak di desa -desa bentaran sungai kalimantan tengah
b. Mendirikan perpustakaan rumah anak dan pusat belajar masyarakat di desa- desa bentaran kalimantan tengah.
c. Meningkatkan kesadaran bagi generasi muda kalimantan tengah akan pentingnya pendidikan,sekolah, pendidikan lingkungan hidup dan kesehatan melalui program-program kelas ransel buku.
d. Meningkatkan sumber daya manusia melalui pelatihan.

\section{Program Ransel Buku}

Ransel buku merupakan lembaga TBM yang memiliki beberapa jenis program yaitu: membaca buku, belajar mengajar, daur ulang sampah, daur ulang kertas, mennyanyi, bercocok tanam, menonton film motivasi, 
Jurnal Pendidikan Guru Sekolah Dasar belajar komputer, tarai tradisional, dan perahu ransel buku. dibawah ini merupakan bagan dari program Ransel Buku:

\begin{tabular}{|c|l|}
\hline No & PROGRAM \\
\hline I & Membaca Buku \\
\hline 2 & Belajar Mengajar \\
\hline 3 & Daur Ulang Sampah \\
\hline 4 & Daur Ulang Kertas \\
\hline 5 & Menyanyi \\
\hline 6 & Bercocok Tanam \\
\hline 7 & Menonton Film \\
\hline 8 & Belajar Komputer \\
\hline 9 & Belajar Tari Tradisional \\
\hline 10 & Perahu Ransel \\
\hline
\end{tabular}

\section{Sarana dan Prasarana}

Ransel Buku memiliki beberapa jenis sarana dan prasarana seperti bangunan ransel buku, perahu ransel buku, laptop, printer, projektor, wireles, speaker, layar projektor, blender, gitar, alat musik tradisional, kipas angin, papan tulis, meja belajar, lemari, rak buku, buku bacaan dan alat-alat belajar sebagai penunjang kegiatan di ransel buku. Berikut ini merupakan sarana dan prasarana yang dimiliki TBM Ransel Buku :

Tabel sarana dan prasarana

\begin{tabular}{|c|l|c|}
\hline No & \multicolumn{1}{|c|}{ Nama Barang } & Jumlah \\
\hline I & $\begin{array}{l}\text { Bangunan dan } \\
\text { Rumah Ransel Buku }\end{array}$ & 2 rumah \\
\hline 2 & Perahu Ransel Buku & I unit \\
\hline 3 & Laptop & 3 unit \\
\hline 4 & Printer & I unit \\
\hline 5 & Projektor & 2 unit \\
\hline 6 & Wirelles & I unit \\
\hline 7 & Speaker & I unit \\
\hline 8 & Layar projector & I unit \\
\hline 9 & Blender & I unit \\
\hline I0 & Gitar & 2 unit \\
\hline II & Alat Musik & 2 unit \\
\hline I2 & Tradisional & \\
\hline I3 & Papas Angin & 4 unit \\
\hline I4 & Meja Belajar & I unit \\
\hline I5 & Lemari & I0 unit \\
\hline I6 & Rak Buku & 3 unit \\
\hline
\end{tabular}

'Saiffullah Darlan, ${ }^{2}$ Seth Miko dan ${ }^{3}$ Wahidin

\begin{tabular}{|c|l|c|}
\hline 17 & Buku Bacaan & \multicolumn{2}{|c|}{4.500 judul } \\
\hline 18 & Alat -Alat Belajar & I Set \\
\hline
\end{tabular}

Pembahasan

TBM sebagai support system berfungsi memberikan dukungan terhadap program induk PNFI yang telah ada.Keberadaan TBM sebagai penguat minat baca dikalangan warga belajar. Minat baca itu sendiri merupakan sikap positif yang harus dimiliki oleh setiap manusia sebagai upaya untuk membangun diri dengan pengetahuan. Melalui keberadaan TBM, diharapkan mampu menstimulasi minat baca sekaligus memfasilitasi kebutuhan masyarakat akan bahan bacaan yang positif. Nantinya, minat baca tersebut diharapkan akan mendarah daging dan menjadi suatu kebutuhan maupun budaya. Akan tetapi konsep tersebut tidaklah mudah untuk dijalani. Berbagai macam sarana serta penambahan koleksi bahan bacaan mutlak dibutuhkan untuk mencapai tujuan tersebut.

Strategi ini layak dikembangkan karena memuat pengembangan TBM untuk menarik minat baca masyarakat. Sarana yang memadai lebih lengkap ditunjang dengan strategi yang tepat dan efisien, strategi dengan sentuhan modern untuk meningkatkan minat baca masyarakat yang mengikuti perkembangan teknologi dan informasi sekarang ini. Ditambah lagi dengan adanya pandemic covid 19 seperti sekarang ini, yang mana menuntut pengeolala TBM Ransel Buku untuk terus berbenah dan berinovatif guna mempertahankan minat baca pengunjung yang sempat mengalami penurunan dari tahun sebelumnya, inilah yang menjadi pekerjaan dan bahan pertimbangan bagi pengelola untuk meningkatkan pelayanan dalam masa pandemic seperti sekarang ini.

Sebagai gambaran TBM Ransel Buku ini dapat dideskripsikan melalui analisis SWOT sebagai berikut:

Tabel Analisis SWOT

\begin{tabular}{l|l|l} 
ANALISIS & Strength & Weakness \\
\hline
\end{tabular}


Jurnal Pendidikan Guru Sekolah Dasar

\begin{tabular}{|c|c|c|}
\hline \multirow[t]{7}{*}{$\begin{array}{l}\text { SWOT TBM } \\
\text { Ransel Buku }\end{array}$} & $\begin{array}{l}\text { a. Memiliki } \\
\text { ruangan } \\
\text { sendiri yang } \\
\text { memadai } \\
\end{array}$ & $\begin{array}{l}\text { a. Kurangnya } \\
\text { Fasilitas } \\
\text { Internet }\end{array}$ \\
\hline & \multirow{3}{*}{$\begin{array}{l}\text { b. Jumlah } \\
\text { masyarakat } \\
\text { yang dekat } \\
\text { dengan TBM } \\
\text { cukup banyak } \\
\text { dan dengan } \\
\text { lokasi yang } \\
\text { strategis } \\
\text { sebagai } \\
\text { tempat } \\
\text { mengembangk } \\
\text { an minat baca } \\
\end{array}$} & $\begin{array}{c}\text { b. Kurangnya } \\
\text { sumberday } \\
\text { a manusia }\end{array}$ \\
\hline & & $\begin{array}{l}\text { c. Koleksi } \\
\text { Buku } \\
\text { bacaan } \\
\text { yang } \\
\text { belum } \\
\text { lengkap }\end{array}$ \\
\hline & & \multirow{4}{*}{$\begin{array}{l}\text { d. buku } \\
\text { yang } \\
\text { dimiliki } \\
\text { terkesan } \\
\text { kurang } \\
\text { abded. }\end{array}$} \\
\hline & $\begin{array}{l}\text { c. Sarana } \\
\text { prasarana } \\
\text { yang relative } \\
\text { sesuai dengan } \\
\text { kebutuhan } \\
\text { pengunjung } \\
\text { meskipun } \\
\text { belum } \\
\text { dilengkapi } \\
\text { dengan } \\
\text { fasilitas } \\
\text { internet yang } \\
\text { memadai. }\end{array}$ & \\
\hline & d. Kemitraan & \\
\hline & $\begin{array}{l}\text { e. Koleksi bahan } \\
\text { bacaan yang } \\
\text { sesuai dengan } \\
\text { lingkungan } \\
\text { keberadaan } \\
\text { TBM Ransel } \\
\text { Buku }\end{array}$ & \\
\hline \multicolumn{3}{|l|}{ Opportunity } \\
\hline $\begin{array}{l}\text { a. Adanya } \\
\text { dukungan } \\
\text { dari Bank } \\
\text { Indonesia }\end{array}$ & $\begin{array}{l}\text { a. Dalam bentuk } \\
\text { Pembuatan } \\
\text { Papan Nama } \\
\text { Ransel Buku }\end{array}$ & $\begin{array}{l}\text { a. Sumbanga } \\
\text { n bahan } \\
\text { bacaan } \\
\text { serta } \\
\text { Perahu } \\
\text { Ransel } \\
\text { Buku } \\
\end{array}$ \\
\hline $\begin{array}{l}\text { b. Adanya } \\
\text { dukungan } \\
\text { dari } \\
\text { pemerinta } \\
\text { h }\end{array}$ & $\begin{array}{l}\text { b. Dalam Bentuk } \\
\text { Donasi Dana } \\
\text { sebagai } \\
\text { penunjang } \\
\text { sarana dan } \\
\text { prasarana }\end{array}$ & $\begin{array}{l}\text { b. Bahan } \\
\text { Bacaan }\end{array}$ \\
\hline $\begin{array}{l}\text { c. Dari David } \\
\text { Metcalf } \\
\text { Salaha satu } \\
\text { Turis asing } \\
\text { yang pada } \\
\text { saat itu } \\
\text { melakukan }\end{array}$ & $\begin{array}{l}\text { c. Donasi dana } \\
\text { sebagai } \\
\text { penunjang } \\
\text { sarana dan } \\
\text { prasarana di } \\
\text { Ransel Buku }\end{array}$ & $\begin{array}{l}\text { c. Dan dalam } \\
\text { bentuk } \\
\text { bahan } \\
\text { bacaan }\end{array}$ \\
\hline
\end{tabular}

\begin{tabular}{|c|c|c|}
\hline $\begin{array}{l}\text { susur } \\
\text { sungai } \\
\text { kemudian } \\
\text { melihat } \\
\text { adanya } \\
\text { ransekl } \\
\text { buku dan } \\
\text { berinisiatif } \\
\text { membantu } \\
\text {. }\end{array}$ & & \\
\hline \multicolumn{3}{|c|}{ Threats } \\
\hline $\begin{array}{l}\text { a. Keberlang } \\
\text { sungan } \\
\text { TBM } \\
\text { Karena } \\
\text { Kemajuan } \\
\text { teknologi } \\
\text { yang } \\
\text { semakin } \\
\text { pesat }\end{array}$ & $\begin{array}{l}\text { a. Keberlanjutan } \\
\text { TBM Ransel } \\
\text { Buku } \\
\text { Mengingat } \\
\text { Ransel Buku } \\
\text { ini sangat } \\
\text { Bergantung } \\
\text { dari pihak lain } \\
\text { sebagai } \\
\text { donator baik } \\
\text { dalam bentuk } \\
\text { buku bacaan } \\
\text { dana }\end{array}$ & $\begin{array}{l}\text { a. Komitmen } \\
\text { para } \\
\text { pengelola } \\
\text { TBM } \\
\text { Ransel } \\
\text { Buku, yang } \\
\text { mana para } \\
\text { pengelola } \\
\text { juga tidak } \\
\text { bias } \\
\text { sepenuhny } \\
\text { a } \\
\text { menggantu } \\
\text { ngkan } \\
\text { hidupnya } \\
\text { pada } \\
\text { Ransel } \\
\text { Buku }\end{array}$ \\
\hline
\end{tabular}

Perahu Ransel Buku sebagai sarana transportasi untuk menuju desa-desa disekitarnya sebagai upaya memenuhi kebutuhan minat baca masyarakat yang tidak memiliki sarana dan prasarana berkaitan dengan ketersedian bahan bacaan.

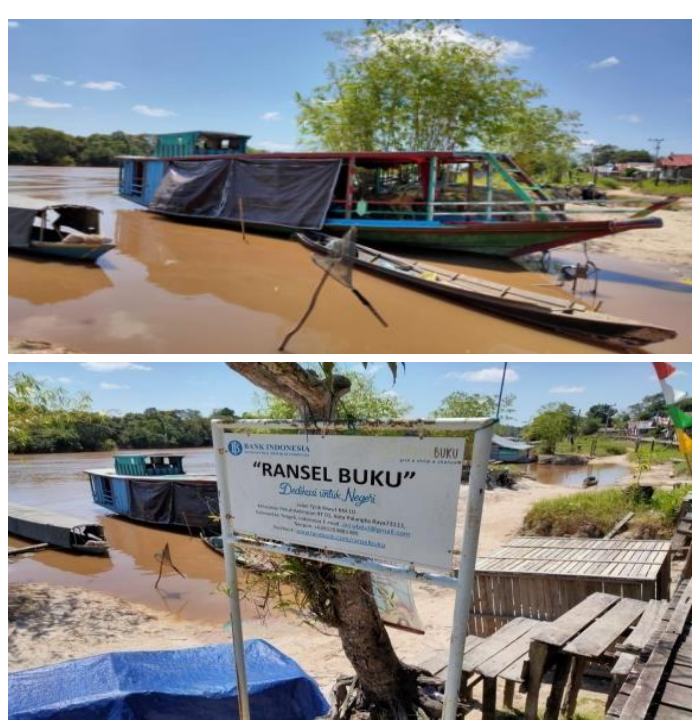




\section{TUNAS}

Jurnal Pendidikan Guru Sekolah Dasar Gambar : Papan Nama TBM Ransel Buku dan Perahu Ransel Buku

Hasil yang Dicapai

Hasil yang dicapai melalui optimalisasi layanan TBM Ransel Buku terhadap peningkatan minat baca masyarakat adalah aktivitas membaca bisa menjadi budaya bagi Pengunjung dalam menambahkan segi pengetahuan. $\mathrm{Hal}$ ini ditunjukan dengan jumlah pengunjung pada tahun 2019 sebagaimana table di bawah ini:

Tabel: Data Awal Pengunjung TBM Ransel Buku Tahun 2019

\begin{tabular}{|l|l|c|}
\hline Tahun & \multicolumn{1}{|c|}{ Bulan } & $\begin{array}{c}\text { Jumlah } \\
\text { Pengunjung }\end{array}$ \\
\hline \multirow{8}{*}{2019} & Januari & 50 \\
\cline { 2 - 3 } & Februari & 48 \\
\cline { 2 - 3 } & Maret & 45 \\
\cline { 2 - 3 } & April & 50 \\
\cline { 2 - 3 } & Mei & 47 \\
\cline { 2 - 3 } & Juni & 49 \\
\cline { 2 - 3 } & Juli & 50 \\
\cline { 2 - 3 } & Agustus & 48 \\
\cline { 2 - 3 } & September & 49 \\
\cline { 2 - 3 } & Oktober & 47 \\
\cline { 2 - 3 } & November & 50 \\
\cline { 2 - 3 } & Desember & 47 \\
\hline
\end{tabular}

Dari tabel diatas dapat dilihat garafik pengunjung TBM Ransel Buku berikut selama tahun 2019

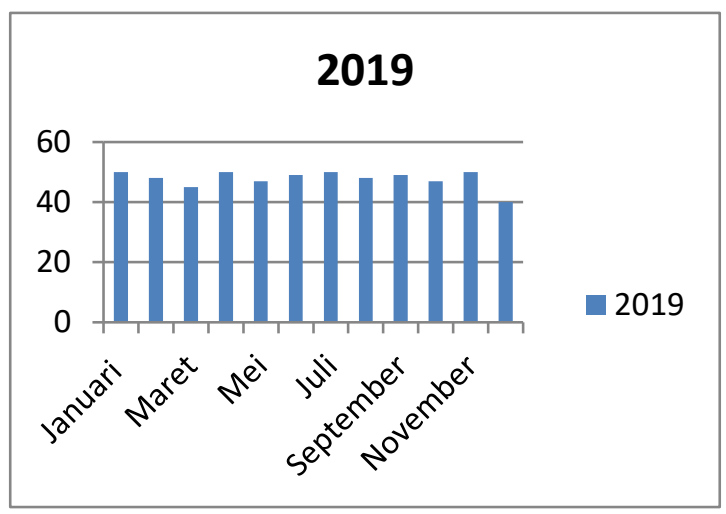

\section{Gambar: Grafik Pengunjung TBM Ransel Buku Tahun 2019}

Sedangkan data pengunjung setelah memasuki masa pandemi covid 19 di tahun 2020 sempat mengalami penurunan yang cukup drastis, namun pihak TBM Ransel Buku berupaya memperbaiki sistem pelayanan yang mengacu pada protokol kesehatan guna menciptakan rasa aman rasa nyaman dan kepercayaan pengunjung TBM dimasa pandemi sehingga mulai bulan juli hingga oktober sudah mulai ada peningkatan jumlah pengunjungnya dan dapat dilihat pada table dan grafik dibawah ini.

Tabel: Data Pengunjung TBM Ransel Buku Tahun 2020

\begin{tabular}{|l|l|c|}
\hline Tahun & \multicolumn{1}{|c|}{ Bulan } & $\begin{array}{c}\text { Jumlah } \\
\text { Pengunjung }\end{array}$ \\
\hline 2020 & Januari & 49 \\
\cline { 2 - 3 } & Februari & 43 \\
\cline { 2 - 3 } & Maret & 35 \\
\cline { 2 - 3 } & April & 17 \\
\cline { 2 - 3 } & Mei & 12 \\
\cline { 2 - 3 } & Juni & 14 \\
\cline { 2 - 3 } & Juli & 27 \\
\cline { 2 - 3 } & Agustus & 32 \\
\cline { 2 - 3 } & September & 38 \\
\cline { 2 - 3 } & Oktober & 46 \\
\hline
\end{tabular}

Grafik jumlah pemgunjung TBM Ransel Buku di masa Pandemi Covid 19 dari Bulan Januari-Oktober 2020 dapat dilihat pada table berikut.

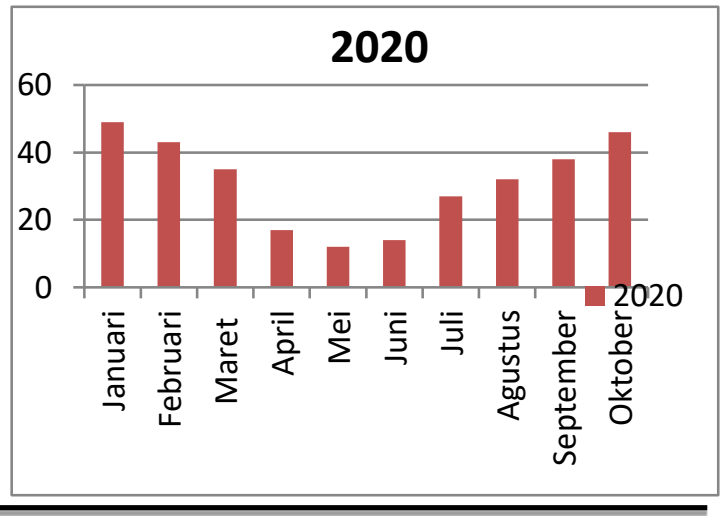

'Saiffullah Darlan, ${ }^{2}$ Seth Miko dan ${ }^{3}$ Wahidin 
Jurnal Pendidikan Guru Sekolah Dasar

Gambar. 5.8 grafik jumlah pengunjung TBM Ransel Buku Tahun 2020

Adapun secara grafik jumlah pengunjung TBM Ransel Buku sebelum, masa pandemi covid 19, saat pandemi, dan setelah lock down pandemi dapat dilihat pada grafik di atas (tabel jumlah pengunjung).

Sedangkan untuk perbandingan grafik perbandingan jumlah pengunjung tahun 2019 sebelum Pandemi Covid 19 dan pada tahun 2020 saat memasuki masa pandemi dapat dilihat dari table dan grafik berikut ini.

Tabel Jumlah Pengunjung TBM Ransel Buku Tahun 2019 dan 2020

\begin{tabular}{|l|c|c|}
\hline \multirow{2}{*}{ Bulan } & \multicolumn{2}{|c|}{ Jumlah Pengunjung } \\
\cline { 2 - 3 } & 2019 & 2020 \\
\hline Januari & 50 & 49 \\
\hline Februari & 48 & 43 \\
\hline Maret & 45 & 35 \\
\hline April & 50 & 17 \\
\hline Mei & 47 & 12 \\
\hline Juni & 49 & 14 \\
\hline Juli & 50 & 27 \\
\hline Agustus & 48 & 32 \\
\hline September & 49 & 38 \\
\hline Oktober & 47 & 46 \\
\hline November & 50 & \\
\hline Desember & 47 & \\
\hline
\end{tabular}

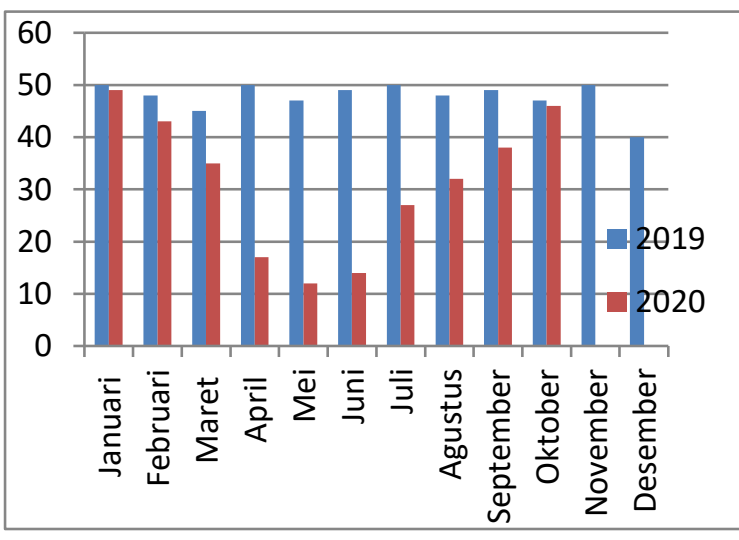

Gambar: Grafik Jumlah Pengunjung TBM Ransel Buku Tahun 2019 dan 2020
Dari data diatas terlihat jelas perbedaan jumlah pengunjung pada sebelum pandemi dan setelah memasuki masa pandemi yang sempat mengalami penurunan yang ahirnya pihak pengelola TBM Ransel Buku berupaya memperbaiki sistem pelayanan dengan menerapkan protokol kesehatan guna mengembalikan kepercayaan pengunjung dan masyarakat dengan harapan minat baca pengunjung tidak terpengaruh dengan kondisi pandemi seperti sekarang ini. Hal ini dilakukan mengingat antusias warga terutama anak-anak untuk berkunjung ke TBM sangat tinggi dan hal tersebutlah yang menjadi tekat dan komitmen pengelola TBM untuk selalu berupaya semaksimal mungkin untuk memberikan pelayan yang terbaik bagi pengunjung dan masyarakat pada umumnya.

I. Faktor Pendukung

a. Dukungan masyarakat Petuk Katimpun yang siap berpartisipasi pada program-program kerja TBM sebagai upaya demi kemajujuan TBM Ransel Buku kedepan.

b. Dukungan dari pemerintah dan pihak swasta maupun perorangan yang memiliki kepedulian terhadap minak baca masyrakat dan dukungng dengan solidaritas dan loyalitas pengelola TBM yang pantang menyerah.

2. Kendala yang Dihadapi

a. Kendala yang dihadapi TBM Ransel Buku belum tersedianya fasilitas Internet Berupa Jaringan Wifi dan hanya mengandalkan koneksi dari jaringan ponsel sebagai sarana untuk mengakses informasi dari internet.

Sumber Daya Manusia sebagai pengelola TBM yang hanya satu orang yang berlatar pendidikan SI dan dibantu beberapa lainya, dari latar belakang pendidikan SMA dan juga adanya partisipasi warga yang berkunjung ke TBM tersebut yang jauh dari kata profesional untuk mengelola TBM tersebut. 


\section{Jurnal Pendidikan Guru Sekolah Dasar KESIMPULAN}

Berdasarkan hasil pengamatan dan analisis data maka dapat disimpulan sebagai berikut:

I. Sistem pelayanan yang diterapkan di TBM Ransel Buku sudah mengacu pada protokol kesehatan hal ini dilihat dari upaya pengelola menerapkan metode pelayanan yang dilengkapi dengan sarana cuci tangan dan pengecekan suhu badan setiap pengunjung serta pengaturan jarak tempat duduk pengunjung. Artinya, pengelola pengelola berupaya menciptakan rasa aman dan menjaga kepercayaan pengunjung dan masyarakat guna mempertahankan minat baca pengunjung di TBM tersebut.

2. Sistem pelayanan yang dilakukan di TBM Ransel Buku yang sudah menerapkan Protokol Kesehatan dapat mengembalikan minat pengunjung yang sempat menurun pada saat masa pandemic covit 19 dan ahirnya jumlah pengunjung pun berangsur meningkat. Yang artinya ada kepercayaan masyarakat kepda pengelola TBM Ransel Buku dalam menjaga kesehatan dan keselamatan pengunjung dari wabah covit 19 yang sedang mewabah saat ini.

\section{DAFTAR PUSTAKA}

Arikunto, S. (2006). Prosedur Penelitian, Suatu Pendekatan Praktek.Jakarta: Rineka Cipta.

Creswell, J. (2010). Research Design Pendekatan Kualitatif, Kuantitatif, dan Mixed. Third ed. Yogyakarta: Pustaka Pelajar.

Departemen Pendidikan dan Kebudayaan. 1999. Kamus Besar Bahasa Indonesia. Balai Pustaka, Jakarta

Departemen Pendidikan Nasional. (2003). Undang-Undang Nomor 20 Tahun 2003, tentang Sistem Pendidikan Nasional. Jakarta: Depdiknas

Direktorat Pembinaan Pendidikan Keaksaraan dan Kesetaraan. (2016). Petunjuk Teknis Bantuan Sarana TBM dan Prosedur Pengajuan Bantuan Tahun 2016. Jakarta: Direktorat Jenderal Pendidikan Anak Usia Dini dan Pendidikan Masyarakat, Kementerian Pendidikan dan Kebudayaan.

Dawson, Mildred A. \& Hendry A. Bamman. (20I5). Fundamentals of Basic Reading. Instruction. New York: Longmans, Green and Co.

Jene, Octroaica Cempaka. BYPMYRR, Yuniwati dan Rohmiyati, Yuli. (20l3). Peran Taman Bacaan Masyarakat Dalam Menumbuhkan Budaya Baca Anak di Taman Bacaan Masyarakat "Mortir" Banyumanik-Semarang. Jurnal IImu Perpustakaan.

Karyanti \& M.A Setiawan. 2019. Pengembangan Model Konseling Kelompok Teknik Expresif Writing Berlandaskan Falsafah Dandang Tingang Untuk Meningkatkan Perilaku Respect. JURKAM, 3(I):33-39.

Kementerian Pendidikan dan Kebudayaan.

(20I3). Permendikbud No. 8I Tahun 2013 tentang Pendirian Satuan Pendidikan Nonformal. Jakarta: Kemdikbud.

Neuman, W. Lawrence. (2016). Metodologi Penelitian Sosial. Pendekatan Kualitatif dan Kuantitatif. Edisi 7 (Terjemahan Edina T. Sofia). Jakarta : PT. Indeks.

Noorhidawat, A and Gibb, Forbes. (2009). How Students Use e-books-Reading or Referring? Malaysian Journal of Library and Information Science 13, Malaysia: Wilson Select Plus. Database Online.

Rahim, Farida. (2008). Pengajaran Membaca di Sekolah Dasar. Jakarta: Bumi Aksara.

Sudjana, H.D. (2004). Pendidikan Non Formal, Bandung: Falah Production.

Tamba, Wayan, Rizka, MA, Andriani, Ika. (2020). Pendidikan Masyarakat Melalui 


\section{TUNAS}

Jurnal Pendidikan Guru Sekolah Dasar

Pemberdayaan Perempuan Berbasis Life

Skill Education. Jurnal Paedagogy:Jurnal

Penelitian dan Pengembangan

Pendidikan

Wahadaniah, Herman. 2007. Perpustakaan

Sekolah sebagai Sarana Pengembangan

Minat dan Kegemaran Membaca. Dalam

Departemen Pendidikan dan

Kebudayaan. Laporan Lokakarya

Pengembangan Minat dan Kegemaran

Membaca (hlm. I5-22) Jakarta:

Departemen Pendidikan dan

Kebudayaan.

Yulaelawati, Ella. 2010. Taman Bacaan Masyarakat Kreatif. Jakarta: Direktorat Pendidikan Masyarakat, Direktorat Jendral Pendidikan Nonformal dan Informal Kementerian Pendidikan Nasional.

Zuriah, Nurul. 2009. Metodologi Penelitian Sosial Pendidikan Teori-Aplikasi. Jakarta: PT. Bumi Aksara.

http://edefinisi.com/tag/definisi-keberaksaraan diakses tanggal 19 April 2018.

http://id.wikipedia.org/wiki/pendidikanluarsek olah diakses tanggal 12 Februari 2019 